\title{
The International Conference on the Great Lakes Region and the implementation of the Ezulwini Consensus: Challenges and prospects
}

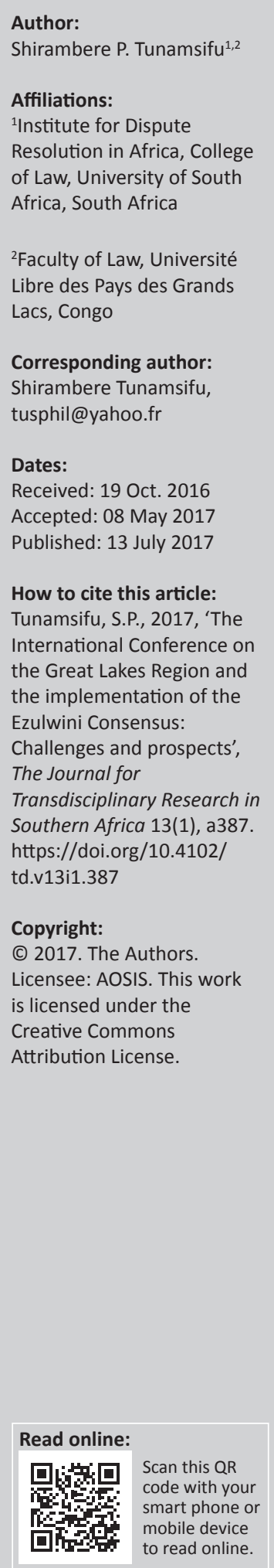

This article is evaluative assessing the implementation of the Ezulwini Consensus by the International Conference on the Great Lakes Region (ICGLR). In early April 2012, a mutiny started in the eastern part of the Democratic Republic of the Congo (DRC), resulting in the creation of the rebel group known as the Mouvement du 23 Mars (M23). The spread of M23 constituted a serious threat to peace, security and stability in the entire African Great Lakes region. On the basis of the Ezulwini Consensus, which emphasises that regional organisations in areas of proximity to conflicts should be empowered to take action, the ICGLR resolved to intervene. Through several summits attempting to find a home-grown solution, the ICGLR faced two main challenges in implementing the Ezulwini Consensus. The first was related to the lack of actions and sanctions against member states that violated fundamental principles and the second was related to the lack of neutrality of the chairperson of the ICGLR during the dialogue between the government of the DRC and M23. The intervention of the ICGLR is important, but in such circumstances, it is crucial that member states demonstrate their political will to respect fundamental principles and sanction members that allegedly ignore these principles. In the mediation process, where there is sufficient evidence to indicate that a member state is allegedly providing support to rebel groups that are destabilising another member state, it is important that the ICGLR adopt a policy of requesting such a country to avoid taking the lead in or mediating the conflict. However, when regional organisations in areas of conflict face such challenges, the African Union must take responsibility for comediating or sending African experts to resolve the conflict impartially.

\section{Introduction}

The Ezulwini Consensus is a common African position on the proposed reform of the United Nations (UN) adopted by the African Union (AU) following the report of the High-level Panel on Threats, Challenges and Change. The Ezulwini Consensus was adopted during the Executive Council's 7th Extraordinary Session of 7-8 March 2005 held in Addis Ababa, Ethiopia. It contains three elements: collective security and the challenge of prevention, collective security and the use of force and institutional reform. This paper focuses mainly on collective security and the use of force. However, the latter element of the Ezulwini Consensus is one of the objectives for which the UN was created to maintain international peace and security, as provided for in Article 2.7 of the UN Charter (hereafter the Charter). To this end, member states of the UN have transferred this primary responsibility to the Security Council (Article 24.1).

As conflicts are inescapable facts of human existence, the Charter encourages regional arrangements for appropriate responses to matters relating to the maintenance of international peace and security (Article 52). In this regard, at the continental level, the AU has an array of bodies tasked with maintaining international peace and security, as provided for in the AU Constitutive Act and its protocol on the establishment of the Peace and Security Council (PSC). Without undermining the responsibility of the international community, the AU has resolved that when conflict occurs, nearby regional organisations should take action. In such circumstances requiring urgent action, the UN should assume responsibility for financing such operations (African Union 2005).

Indeed, in early April 2012 a mutiny started in the North Kivu Province of the Democratic Republic of the Congo (DRC), resulting in the creation of the rebel group known as the Mouvement

Note: This article is based on work previously published by the author Shirambere P. Tunamsifu 'Challenges and prospects of AU to implement the Ezulwini Consensus: The case of collective security and the use of force'. Published article: http://www. monitor.upeace. org/archive.cfm?id_article=1045 
du 23 Mars (M23). After taking control of most localities in the territory of Rutshuru, in mid-November 2012, M23 occupied the town of Goma (capital of the North Kivu province). The purpose of M23 rebels was to put pressure on the government to ensure that the peace agreement of 23 March was fully implemented (RDC 2009). ${ }^{1}$

Indeed, Human Rights Watch (HRW 2013) and the UN Joint Human Rights Office (UNJHRO 2013, 2014) documented several allegations of serious violations committed by M23 rebels. They have summarily executed civil population, raped women and girls, forced recruitment of men and boys in both Rwanda and DRC, and looted civilian properties.

Concerned with the humanitarian disaster caused by the spread of the M23 rebellion, the International Conference on the Great Lakes Region (ICGLR), as the regional organisation in the area, took action that resulted in several extraordinary summits of heads of state and government in order to find a home-grown solution to the conflict. To this end, a dialogue was held in Kampala between the government of the DRC and M23 under the mediation of the Chairperson of the ICGLR, H. E. President Yoweri Museveni of Uganda. During the period when the ICGLR took the initiative to intervene, on 12 November 2012 the UN Group of Experts on the DRC delivered a report emphasising that the creation and sustainability of the M23 rebellion had received extensive foreign support from the government of Rwanda and from senior officials in the government of Uganda (UNSC 2012b).

Therefore, the challenges the ICGLR faced in implementing the Ezulwini Consensus that this paper attempts to analyse can be separated into two elements. The first challenge relates to the lack of action against member states that violated fundamental principles. The second relates to the lack of neutrality of the chairperson of the ICGLR during the dialogue between the government of the DRC and the M23 rebel group.

This paper begins with a reflection on the Ezulwini Consensus regarding collective security and the use of force within the frameworks of the responsibility to protect (R2P). It then analyses the challenges in implementing the Ezulwini Consensus and their implications. Next, it presents the prospects for implementing the Ezulwini Consensus. Lastly, it presents concluding remarks.

\section{The Ezulwini Consensus within the responsibility to protect framework}

The Ezulwini Consensus, as it relates to collective security and the use of force, is in conformity with the framework of the UN, the AU and the ICGLR regarding the R2P:

The responsibility to protect implies a duty to react to situations in which there is compelling need for human protection.

1.It is about the return of Congolese refugees in neighbouring countries (Article 6 [1]) to reform the security sector services (Article 10) and grant ranks to former National
Congress for the Defense of the People rebels integrated in the police and the Congress for the Defense of the People rebels integrated in the police and the Armed Forces of the Democratic Republic of the Congo (Article 12[7]).
If preventive measures fail to resolve or contain such a situation, and when the state in question is unable or unwilling to step in, then intervention by other states may be required. Coercive measures then may include political, economic, or judicial steps. In extreme cases they may also include military action. (Evans \& Sahnoun 2002:102-103)

In this light, collective security can be referred to as:

a system, regional or global, in which each state in the system accepts that the security of one is the concern of all, and agrees to join in a collective response to threats to, and breaches of, the peace. (Roberts \& Zaum 2008:11)

\section{Under the United Nations Charter}

The system of collective security under the Charter is reflected in Article 24(1). In this provision, member states of the UN confer on the United Nations Security Council (UNSC) primary responsibility for the maintenance of international peace and security, and agree that in carrying out its duties under this responsibility, the UNSC acts on their behalf. However, one should bear in mind that Article 2(4) of the Charter prohibits the threat or use of force against the territorial integrity of any state. The exception to this provision is a case of self-defence or the use of force authorised by the UNSC under Chapter VII of the Charter (as provided for in Article 51). Where there is a threat to peace, breach of the peace or act of aggression, Article 39 of the Charter provides that the UNSC may make recommendations on, or decide, what measures shall be taken to maintain or restore international peace and security. Such measures may not involve force, such as partial interruption of economic relations, under Article 41 of the Charter, or may involve the use of force as provided in Article 42 of the Charter.

In the Millennium Report of the UN Secretary-General, Annan (2000) acknowledged that the principles of sovereignty and non-interference offer vital protection to small and weak states. However, to the critics, he posed the following question:

If humanitarian intervention is, indeed, an unacceptable assault on sovereignty, how should we respond to a Rwanda, to a Srebrenica - to gross and systematic violations of human rights that offend every precept of our common humanity? (p. 48)

On the dilemma of humanitarian intervention and the defence of the sovereignty principle, Annan (2000) stated that:

[w] here such crimes occur and peaceful attempts to halt them have been exhausted, the Security Council has a moral duty to act on behalf of the international community. The fact that we cannot protect people everywhere is no reason for doing nothing when we can. Armed intervention must always remain the option of last resort, but in the face of mass murder it is an option that cannot be relinquished. (p. 48)

From the above, the dilemma is justified in accordance with international law, particularly the purposes and principles of the Charter Article 2(1.7), which underlines the principles of sovereignty and non-interference. However, these principles 
do not allow any sovereign state to abuse the human rights of its own people by evoking domestic jurisdiction. In other words, there is a limit to the principles of sovereignty and noninterference when a government is unwilling or fails to protect its own nationals, because sovereignty is also the capacity of a state to be able to protect its own peoples and its borders. In this regard, Nanda (2007) argues that a government can no longer:

hide behind the shield of sovereignty, claiming non-intervention by other states in its internal affairs, if it fails to protect the people under its jurisdiction from massive violations of human rights. (p. 373)

Accordingly, the report presented by the International Commission on Intervention and State Sovereignty (ICISS 2001) in December 2001 on the R2P, marked a new milestone in international humanitarian law. The theme reflects:

the idea that sovereign states have a R2P their own citizens from avoidable catastrophe - from mass murder and rape, from starvation - but that when they are unwilling or unable to do so, that responsibility must be borne by the broader community of states. (p. VIII)

Concerning collective security, the High-Level Panel on threats to the UN, challenges and change has endorsed the same point of view. In addition, the report mentions that when a state fails to protect its citizens, the international community then has a responsibility to act, through humanitarian operations, monitoring missions and diplomatic pressure - and with force if necessary, though only as a last resort.

It is in this context that the UN General Assembly (UNGA) adopted Resolution 60/1 (the 2005 World Summit Outcome). Paragraphs 138 and 139 of the resolution provide that each individual state has the R2P its populations from genocide, war crimes, ethnic cleansing and crimes against humanity. In addition, the international community, through the UN, has the responsibility to use appropriate diplomatic, humanitarian and other peaceful means, in accordance with Chapters VI and VIII of the Charter, to help to protect populations from the aforementioned crimes. In this context, the international community is prepared to take collective action, in a timely and decisive manner, through the UNSC, in accordance with the Charter, especially Chapter VII, on a case-by-case basis and in cooperation with relevant regional organisations as appropriate, should peaceful means be inadequate and national authorities are manifestly failing to protect their populations (UNGA 2005).

\section{Under the Constitutive Act of the African Union}

African heads of state and government, conscious of the fact that the scourge of conflict constitutes a major impediment to development, resolved to replace the Organisation of African Unity by unanimously adopting the Constitutive Act of the AU (hereafter the Act) in 2000.

Indeed, Article 3(f, h) of the Act provides for the promotion of peace, security and stability and the promotion and protection of human and peoples' rights on the continent. In contrast to the erstwhile Organisation of African Unity, Article 4(h) of the Act emphasises:

the right of the Union to intervene in a Member State pursuant to a decision of the Assembly in respect of grave circumstances, namely: war crimes, genocide and crimes against humanity.

Thus, desirous of establishing an operational structure for the effective implementation of the decisions taken in the areas of conflict prevention, peace-making, peace support operations and intervention, as well as peace-building and post-conflict reconstruction, the protocol creating the PSC was adopted in accordance with Article 5(2) of the Act. The protocol also integrated Article 4(h), with the objective of anticipating and preventing conflicts (Article 3[b]).

Acting under those provisions, when atrocities were committed against citizens in Darfur (between 2003 and 2005) and Burundi (between 2002 and 2003), the AU was obliged to intervene with the aim of resolving both crises. The AU's Missions in Sudan (AMIS) and in Burundi (AMIB) were deployed in 2003. However, because of financial constraints on the part of the AU during both operations, the UNSC decided to establish international hybrid operations under its own banner.

In order to achieve a more decisive response in such situations, at its 60th session, the UNGA adopted Resolution 60/1, which provides for the R2P in paragraphs 138 and 139. During an extraordinary summit on 7-8 March 2005 in Addis Ababa, heads of state and government of the AU endorsed the R2P in a report known as the Ezulwini Consensus. The report recognises the authority of the UNSC to authorise the use of force in situations of genocide, crimes against humanity, war crimes and ethnic cleansing, and insists that in such cases regional organisations in areas near to conflicts should be empowered to take action (ICRtoP n.d.). As the UNGA and the UNSC are far from the scene, the report insists that in circumstances requiring urgent action, the UNSC should approve and assume responsibility for financing such operations (African Union 2005). However, notwithstanding the right of the $\mathrm{AU}$ to intervene, it cannot protect people everywhere. That is why the UNSC encourages peaceful settlement of local disputes through regional arrangements or regional agencies (Article 52.3 of the Charter). In this regard, the AU has, among other objectives, to coordinate and harmonise the policies of existing and future regional communities (Article 3.1 of the Act); it is the case of the ICGLR among other regional organisations.

\section{Under the Pact on Security, Stability and Development in the Great Lakes Region of the International Conference on the Great Lakes Region}

The ICGLR is an inter-governmental organisation of 12 African member states in the Great Lakes Region (GLR). ${ }^{2}$ It is governed by the Pact on Security, Stability and Development

2.They are following: Angola, Burundi, Central African Republic, Republic of Congo, DRC, Kenya, Uganda, Rwanda, Republic of South Sudan, Sudan, Tanzania and Zambia. 
in the GLR (hereafter the Pact) that was solemnly signed by the heads of state and government in Nairobi in December 2006. The Pact includes 10 protocols and deals with aspects of the R2P. Article 5 of the Pact provides that member states renounce the threat or the use of force against one another. Explicitly, member states acknowledge the responsibility to protect their populations from genocide, war crimes, ethnic cleansing and crimes against humanity through the Protocol on the Prevention and Punishment of international crimes (Article 8).

\section{Challenges and implications of implementing the Ezulwini Consensus}

This section begins with a brief overview of the M23 armed conflict, followed by the challenges faced by the ICGLR in implementing the Ezulwini Consensus.

\section{Brief overview of the Mouvement du 23 Mars armed conflict}

The peace agreement signed on 23 March 2009 between the government of the DRC and the CNDP rebel group allowed former rebels to integrate the Armed Forces of the Democratic Republic of the Congo (FARDC), the police and the provincial government of North Kivu. However, on 14 March 2012, the International Criminal Court's (ICC) judicial decision that found Thomas Lubanga guilty of war crimes (ICC-01/04-01/06-2842 2012:§22-28, 1115) changed the situation on the ground. The ICC issued an arrest warrant for Bosco Ntaganda, who was deputy chief of general staff for military operations of Lubanga's Union des Patriotes Congolais/Forces patriotiques pour la libération du Congo (UPC/FPLC), and integrated into the army with the rank of Brigadier General. Because of international pressure, President Kabila issued an instruction to arrest him (HRW 2012). Subsequently, by the end of March 2012, most of the former CNDP combatants who were integrated in the FARDC and other public institutions deserted from the army, claiming that the DRC government had failed to fully implement the peace agreement of 23 March 2009.

The deserters requested to talk with the government, but President Kabila insisted that they would face military justice instead of reintegration. Following heavy pressure from the FARDC, the mutineers moved out of Masisi where they had fallen back to a narrow stretch of hills close to the Rwandan border. From there, Rwanda became their rear base (Stearns 2012:44) and on 6 May 2012, they announced the creation of M23 as a rebel movement. Gravely concerned by the escalation of the armed conflict in the eastern DRC, the ICGLR, as the regional organisation in the area of conflict, organised several extraordinary summits of heads of state and government as well, as a direct dialogue between the government of the DRC and M23. However, the intervention of ICGLR faced some challenges in implementing the Ezulwini Consensus.

\section{Challenges in implementing the Ezulwini Consensus}

The first challenge relates to a lack of action during several extraordinary summits of the ICGLR against member states violating fundamental principles. The second challenge relates to the neutrality of the chairperson of the ICGLR.

\section{Challenge of the lack of action against member states}

While efforts were undertaken by the ICGLR to resolve the conflict, Rwanda and Uganda were playing a crucial role enabling M23 to emerge, resist and fight against the FARDC.

Indeed, pursuing resolution 1533 (2004), the UN SecretaryGeneral appointed the Group of Experts on the DRC. In its monitoring of the arms embargo, the group's primary role was to investigate and document evidence regarding the procurement of military equipment, including weapons and ammunition, by armed groups active in the DRC, as well as their related financial networks and involvement in the exploitation and trade of natural resources. The findings revealed substantial evidence that Rwandan officials had provided direct military and political assistance in the creation of M23 through allowing them the use of the Rwandan territory. The Group also found evidence that Rwandan officials mobilised ex-CNDP cadres and officers, North Kivu politicians, business leaders and new civilian youth recruits to support and strengthen the ranks of M23 rebels (UNSC 2012a:4-17). During a bilateral meeting between the DRC and Rwanda, the DRC authorities supplied evidence of the Rwandan Defence Force's military support for and weapons delivery to M23. The Rwandan government denied these allegations (UNSC 2012a:24-25).

Under Article 5(1.d) of the Pact, ${ }^{3}$ the government of the DRC requested the ICGLR to intervene, in its capacity as regional organisation, in the conflict situation in the eastern DRC. Thus, a series of extraordinary summits were organised, attempting to find 'a regional solution to regional problem'.

International Conference on the Great Lakes Region Regional Inter-Ministerial Committee and Ministers of Defence of 11 July 2012: As a technical organ, the ICGLR Regional Inter-Ministerial Committee and Ministers of Defence meeting was held at the headquarters of the AU on 11 July 2012 to prepare for the summit of the heads of state and government. At the end of the extraordinary meeting, the following decisions were adopted: the committee strongly condemned the actions of M23 and requested all negative forces, in particular M23, to stop armed activities. The committee resolved that no support should be given to any negative forces destabilising the region and eastern DRC in particular. Finally, the committee called on member states to fully implement the Pact, and in particular the Protocol on Non-Aggression and Mutual Defence (ICGLR 2012a).

3.Article 5(1.d) stipulates that if any member state fails to comply with the Protocol on Non-aggression and Mutual Defence in the Great Lakes Region, an extraordinary summit shall be convened to consider appropriate action. 
Before analysing the decisions taken by the committee on 11 July 2012, it is important to highlight the following observations:

The ICGLR Regional Inter-Ministerial Committee and Ministers of Defence failed to acknowledge the findings of the UN group of experts on the DRC on the involvement of Rwanda in the provision of support to M23 (S/2012/348) or recommend them to the summit of the heads of state and government of the ICGLR. Such support of the rebel group was a violation not only of the arms embargo, but also of the Protocol on Non-aggression and Mutual Defence in the GLR (Article 5 of the Pact). Besides, the support was also in violation of paragraph 5 of the Peace, Security and Cooperation Framework for the DRC and the region (PSC Framework) that calls on states to neither harbour nor provide protection of any kind to persons accused of international crimes.

Indeed, considering the first decision condemning the actions of M23, the ICGLR Regional Inter-Ministerial Committee and Ministers of Defence failed to call on the government of Rwanda to respect the national sovereignty and territorial integrity of the DRC and not to interfere in its internal affairs.

Regarding the second decision requesting all negative forces, in particular M23, to stop armed activities and that no support should be given to any negative forces destabilising the region and eastern DRC in particular, the committee failed to request Rwanda specifically to stop any support to M23 on the basis of evidence from the UN Group of Experts. In addition to this report, the committee took advantage of findings from non-governmental organisations such as Human Rights Watch.

On the third decision calling on member states to fully implement the Pact, and in particular the Protocol on NonAggression and Mutual Defence, the committee failed to anticipate sanctions or possible measures that could be taken against member states violating these instruments.

Extraordinary summit of the heads of state and government of the International Conference on the Great Lakes Region on 15 July 2012: Meeting on the margins of the 19th Ordinary Session of the AU to discuss the security situation in eastern DRC that constituted a serious threat to peace, security, stability and the entire GLR, the heads of state and government of the ICGLR approved and endorsed the report from the extraordinary meeting of the Regional InterMinisterial Committee (ICGLR 2012b).

The heads of state and government also decided that negative forces, in particular M23, should stop armed activities immediately and no support should be given to any negative force attempting to destabilise the region and the eastern DRC in particular. In addition, they called on member states to fully implement the Pact and the Protocol on NonAggression and Mutual Defence in the GLR.

Concerned by the security issues and the fighting between M23 and the FARDC, five heads of state of the 11 countries that at that time composed the ICGLR were present and the ministers represented others. The heads of state and government of the ICGLR made a good decision against the M23 rebel group; however, they failed to request the Rwandan government to respond to the allegations that it supported the group.

Extraordinary summit of the heads of state and government of the International Conference on the Great Lakes Region on 7-8 August 2012: The heads of state and government of the ICGLR, having considered the report of the extraordinary meeting of the Regional Inter-Ministerial Committee, considered that the security and humanitarian situation in eastern DRC constituted a serious threat to peace, security, stability and development in the entire GLR because of the activities of armed groups (ICGLR 2012c). Determined to seek home-grown solutions to the problems of the GLR through established regional mechanisms, the summit adopted the following decisions, among others:

- To stop the fighting in eastern DRC, with the possibility of sanctions against those who obstructed the peace process. However, as in the previous summit, heads of state and government of the ICGLR did not endorse the findings of the UN Group of Experts or request Rwanda to stop any support to the M23 rebel group (S/2012/348).

- To establish a sub-committee consisting of the Ministers of Defence of Angola, Burundi, Congo, DRC, Rwanda, Uganda and Tanzania with the mandate to propose urgent actionable steps to ensure that fighting stopped completely and provide details of the operationalisation of the neutral International Force. However, even though the government of Rwanda denied providing support to the rebel group M23, it would have been better for the Rwandan Minister of Defence to withdraw from the sub-committee to a neutral position. Nevertheless, the ICGLR's summit accepted the participation of the Rwandan minister in the sub-committee.

Sixth extraordinary summit of the heads of state and government of the International Conference on the Great Lakes Region on 31 July 2013: Deeply concerned about the resumption of fighting in eastern DRC, the heads of state and government of the ICGLR called for a quick conclusion to the dialogue between the government of the DRC and M23 by reiterating that the primary responsibility of the GLR was to find lasting solutions to the peace and security challenges in the region (ICGLR 2013a). Besides, they welcomed the adoption by the UNSC of Resolution 2098 in March 2013, establishing the Force Intervention Brigade with responsibility for neutralising armed groups. However, the summit did not take note of the mid-term report of the UN Group of Experts. According to this report:

[s]ince the outset of its current mandate, the Group has to date found no indication of support to the rebels from within Uganda, and has gathered evidence of continuous - but limited - support to M23 from within Rwanda. (UN Group of Experts of the DRC 2013) 
Nevertheless, instead of requesting Rwanda to respond to the continuing allegations, the summit encouraged Rwanda and the DRC to pursue bilateral discussions in order to strengthen confidence and cooperation. However, the government of the DRC requested an extraordinary meeting of the ICGLR because at the bilateral level, the DRC and Rwanda had failed to find a solution regarding evidence of the Rwandan Defence Force's military support of and weapons delivery to M23 rebels. Thus, there was a remarkable imbalance in the handling of complaints against Rwanda when compared to the Sudan's complaint against Uganda for providing arms to Sudanese rebels. In the latter case, the summit had the opportunity to listen to Uganda's response and requested that the Joint Intelligence Fusion Centre reports on the issue be discussed by the Committee of Ministers of Defence for appropriate action.

Seventh extraordinary summit of heads of state and government of the International Conference on the Great Lakes Region: The Ezulwini Consensus recognises that the UNGA and the UNSC are too far removed to understand the situation on the ground at the regional level (ICGLR 2013b). Therefore, there is no reason for the ICGLR to request the UN system to urgently find a definitive solution to the problem of former M23 combatants interned in eastern Rwanda since March 2013.

As the DRC requested the government of Rwanda to extradite former M23 warlords living in Rwanda, the ICGLR could immediately request both countries to undertake cooperation in matters of extradition, judicial investigation and prosecution, as provided by Article 7 of the Pact. Rwanda denied the DRC's request because of the existence of the death penalty in the DRC and because it could not be a neutral prosecutor; therefore, the summit requested both countries to agree that former M23 combatants alleged to have committed crimes under international law be extradited to a third state applying universal jurisdiction where they could be judged.

\section{Challenge to the neutrality of the chairperson of the International Conference on the Great Lakes Region}

This challenge is analysed in accordance with the decision taken by the fifth extraordinary summit of the heads of state and government of the ICGLR on 24 November 2012 (ICGLR 2012).

On 19 November 2012, M23 captured the city of Goma in violation of the request of the previous summit in Kampala on 7-8 August 2012 to stop the fighting. For this reason, the summit decided that the DRC's government should listen to, evaluate and resolve the legitimate grievances of M23, M23 should withdraw at least $20 \mathrm{~km}$ from Goma, and Goma airport should be deployed for a composite force of one company each for the neutral force, for FARDC and for M23, etc. However, unsurprisingly, the extraordinary summit of the heads of state and government did not take note of the report of the group of experts of the UNSC's DRC Sanctions
Committee (S/2012/843), the findings of which demonstrate the following evidence:

The Government of Rwanda continues to violate the arms embargo by providing direct military support to the M23 rebels, facilitating recruitment, encouraging and facilitating desertions from the armed forces of the DRC, and providing arms, ammunition, intelligence and political advice. The de facto chain of command of M23 includes Gen. Bosco Ntaganda and culminates with the Minister of Defence of Rwanda, Gen. James Kabarebe. Following the publication of the addendum to its interim report (S/2012/348/Add.1), the Group met the Government of Rwanda and took into consideration its written response. The Group has, however, found no substantive element of its previous findings that it wishes to alter.

Senior officials of the Government of Uganda have also provided support to $\mathrm{M} 23$ in the form of direct troop reinforcements in Congolese territory, weapons deliveries, technical assistance, joint planning, political advice and facilitation of external relations. Units of the Ugandan People's Defence Forces and the Rwandan Defence Forces jointly supported M23 in a series of attacks in July 2012 to take over the major towns of Rutshuru territory and the Congolese armed forces base of Rumangabo. Both Governments have also cooperated to support the creation and expansion of the political branch of M23 and have consistently advocated on behalf of the rebels. M23 and its allies include six sanctioned individuals, some of whom reside in or regularly travel to Rwanda and Uganda. (UNSC 2012b:3)

From the above, it is clear that the chairperson of the ICGLR, H. E. President Yoweri Museveni, who invited heads of state and government of the ICGLR to the summit on 24 November 2012, was both judge and party in the situation. A mediator is supposed to be neutral, so why did the heads of state and government of the ICGLR endorse President Museveni as facilitator of the dialogue between the DRC government and M23 while Uganda was continually accused of providing support to the rebel group? In such a situation, even if the DRC government did not recuse the mediator, it would have been better for the chairperson of the ICGLR to resign even though he still denied the accusations. In addition, the ICGLR failed to establish a sub-committee with the mandate to deal with those allegations against Rwanda and Uganda in order to take appropriate action, in accordance with the Protocol on Non-aggression and Mutual Defence of the Pact (Article 5).

\section{Prospects for implementing the Ezulwini Consensus}

The R2P implies a duty to react to situations in which there is compelling need for human protection. If preventive measures fail to resolve or contain such a situation, and when the state in question is unable or unwilling to step in, then intervention by other states may be required. Coercive measures then may include political, economic or judicial steps. In extreme cases they may also include military action (Evans \& Sahnoun 2002:102-103). 
Clearly, the R2P embraces three specific responsibilities: the responsibility to prevent, the responsibility to react and the responsibility to rebuild. Indeed, the Ezulwini Consensus has endorsed the R2P by prioritising regional organisations in the areas of conflict to take action in situations of genocide, crimes against humanity, war crimes and ethnic cleansing. As the DRC is situated in the GLR, when bilateral talks with Rwanda did not provide the expected solution, the DRC requested the intervention of the ICGLR. The latter was deeply concerned about the security situation in the eastern DRC that constituted a serious threat to peace, security and development in the entire GLR.

Following requests from the DRC, different extraordinary meetings were held by the ICGLR Regional InterMinisterial Committee and Ministers of Defence as well as by the heads of state and government of the ICGLR. Different declarations reiterated that the primary responsibility of the GLR is to find home-grown solutions to the problems of peace and security in the region. To this effect, the ICGLR decided to intervene through a neutral International Force to eradicate M23 and all negative forces in eastern DRC, and to open a dialogue in Kampala between the government of the DRC and M23 under the mediation of the chairperson of the ICGLR. Thus, working with the AU and the UN, the UNSC decided to establish the Intervention Brigade through Resolution 2098 (2013). Nevertheless, much evidence from the UN Group of Experts and non-governmental organisations proved that the government of Rwanda as well as senior officials of the government of Uganda cooperated to support the creation and expansion of the political branch of M23 and consistently advocated on behalf of the rebels. Besides, both governments violated the arms embargo by providing direct military support to the M23 rebels in the destabilisation of eastern DRC. Nevertheless, the ICGLR lost the opportunity to confront Rwanda and Uganda with those allegations; but the DRC government also failed to request such confrontation or sanction against both countries within the ICGLR.

Based on the above, in order to implement the Ezulwini Consensus, this paper puts forward the following recommendations for better collective security and the use of force in the GLR.

\section{For member states of the International Conference on the Great Lakes Region}

- As the consent to be bound by the Pact and its protocols as expressed by ratification was freely given, member states of the ICGLR solemnly agreed to honour their commitments in a spirit of mutual trust. Article 26 of the Vienna Convention on the Law of Treaties (1969) stipulates that '[e]very treaty in force is binding upon the parties to it and must be performed by them in good faith
(Pacta sunt servanda)'. ${ }^{4}$ Therefore, member states of the ICGLR have to demonstrate their political will to respect the fundamental principles enshrined in the Charter and the AU Constitutive Act, notably the principles of territorial integrity, national sovereignty, non-interference and non-aggression, and prohibit any member state from allowing the use of its territory as a base for aggression or subversion against another member state as expressed by the preamble of the Pact. In so doing, they will ensure the GLR becomes a specific zone of reconstruction and development, as declared in the preamble of the Pact, and create the conditions for security, stability and sustainable development between the member states as provided by Article 2c.

- The ICGLR should not be transformed into a club of friends; instead, it should undertake the required actions to protect populations under imminent threat. In the event, as President Museveni was the chairperson, observers waiting for sanctions against Uganda were disappointed. In such circumstances, for a neutral mediation, it is better to appoint a head of state against whom there are no allegations.

- The member states should demonstrate their capacity to enforce the decisions of the ICGLR in order to protect civilians in member states.

- The member states should renounce the threat or the use of force as policy means to achieve national objectives in the GLR (Article 5a of the Pact).

- The member states should abstain from sending or supporting armed groups into the territory of other member states (Article 5b of the Pact) and abstain from tolerating the presence in their territories of armed groups against the government of another state. If any member state fails to comply with the provisions of this Article, an extraordinary summit should be convened to consider appropriate action (Article 5a of the Pact).

- Alleged perpetrators accused of committing international crimes should not receive any protection from member states of the ICGLR (paragraph 5 of the PSC Framework).

\section{For the African Union}

Since July 2012, the ICGLR has organised around six summits on the conflict in eastern DRC, but some member states such as Rwanda and Uganda have failed to comply with the Pact that created the ICGLR as well as different resolutions of the UNSC. Rwanda has continually been accused of providing military support to the rebel group destabilising the eastern DRC, which constituted a serious threat to peace, security and development in the entire GLR. Furthermore, although Uganda played the role of a mediator between the government of the DRC and M23, it was accused of providing military support to the rebel group.

4.'Pacta sunt servand $a^{\prime}$ is a principle in international law which states that international treaties should be upheld by all the signatories. It is based upon the principle of good faith. 
Because of the dilemmas highlighted above, it is important that in similar situations the AU itself takes responsibility ${ }^{5}$ by sending African experts to help sub-regional organisations to resolve the crisis when the mediator is no longer neutral, as was the case with President Museveni. This could help the AU to take appropriate measures to implement the Ezulwini Consensus. As the situation on the ground is not yet fully restored, or is fragile because of military operations against the Ugandan rebel group Allied Democratic Forces that is perpetrating mass killings of civilians in Beni, the AU must open a permanent office in the eastern DRC that will keep its commission informed on the situation. Collaborating with the UN Mission, the ICGLR, civil society and the representative of the $\mathrm{AU}$ in eastern $\mathrm{DRC}$, being on the ground, will be able to suggest strategies to the AU that will help resolve the cycle of armed conflict and persistent violence by armed groups.

In the Joint ICGLR-Southern African Development Community (SADC) Final Communiqué on Kampala Dialogue signed on 12 December 2013, the ICGLR and SADC 'call upon the international partners, particularly the $\mathrm{UN}$ and the AU to work together and provide support and resources to the Government of the DRC and its follow-up process' (ICGLR-SADC 2013:4). In the researcher's opinion, as there is often bad faith in the implementation of peace deals in the DRC, the Final Communiqué would provide a recommendation requesting the $\mathrm{AU}$ to monitor its enforcement through its permanent office in the eastern DRC as suggested above.

\section{Conclusion}

The protection of populations within the African GLR requires the maintenance of regional peace and security. In this regard, through the Protocol on Non-aggression and Mutual Defence, member states of the ICGLR undertake to renounce the threat or use of force against one another and to abstain from providing support to armed groups. However, when the ICGLR committed to implementing the Ezulwini Consensus, it nevertheless inherited an existing situation in the region in which its members had been involved for two decades. The case of Rwanda and Uganda is eloquent because they have been behind rebel groups in the eastern DRC since 1996, providing direct military support, arms and ammunition to destabilise the DRC for their own economic, political and security interests.

\footnotetext{
5.In the crisis in Burkina Faso where President Compaore attempted to amend the constitution in order to change the presidential term limits, seek re-election in 2015 and extend his 27 years in power (1987-2014), the African Union responded proactively. Concerned to secure the integrity of the constitutional process, the people of Burkina Faso protested against the scheduled debate on the amendment of the Constitution in the National Assembly. As the result of the mass protest, the National Assembly was stormed and the president was forced to resign. Thus, the Economic Community of West African States, as the regional organisation in the area, took the initiative to mediate the crisis, but the African Union rejected a coup d'état following the declaration of the army through Lieutenant Colonel Zida, to install a transitional government for a period of 1 year. In addition the African Union install a transitional government for a period of 1 year. In addition, the African Union gave the army 2 weeks to hand over power to a civilian transitional government, after which it would suspend the country's participation in its activities and impose targeted sanctions (Dersso et al. 2014). Finally, on the African Union's deadline, the parties (religious, military, political, civil and traditional leaders) adopted and signed the charter, setting out a year-long transition to elections and Michael Kafando was named acting president (BBC 2014).
}

Indeed, the willingness of the ICGLR to intervene and eradicate the M23 rebel group would not be sufficient without sanctions against member states that destabilise their neighbours. Unfortunately, despite its several summits, the heads of state and government of the ICGLR did not do so against Rwanda and Uganda. Therefore, it is crucial that member states of the ICGLR demonstrate their political will to respect fundamental principles, particularly territorial integrity, national sovereignty, non-interference and nonaggression against another member state.

Concerning the mediation process, where there is sufficient evidence to indicate that a member state is providing support to rebel groups that are destabilising another member state, it is important that the member states of the ICGLR adopt a policy of requesting the relevant country to avoid taking the lead or mediating in the conflict. In this regard, the President of Uganda as chair of the ICGLR and de facto mediator would be requested to resign from the chairperson and mediator positions on the basis of allegations that senior officials in the government of Uganda were providing support to M23. Even if Uganda were to deny this, Museveni's resignation would allow the ICGLR to find a neutral home-grown solution to the conflict. Thus, in similar situations, this paper recommends that the AU which has the duty to intervene, coordinate and harmonise the policies of regional organisations - takes responsibility for co-mediating or sends African experts to resolve the conflict impartially.

\section{Acknowledgements}

This article is a revised version of a paper entitled 'Challenges and prospects for the AU to implement the Ezulwini Consensus: a case of collective security and use of force' presented at the South African Association of Political Studies on 4 October 2013. Peace and Conflict Monitor of the University for Peace acknowledged it on 20 May 2014.

\section{Competing interests}

The author declares that he has no financial or personal relationships which may have inappropriately influenced him in writing this article.

\section{References}

African Union, 2005, 'The common African position on the proposed reform of the United Nations: The Ezulwini Consensus', viewed 12 August 2013, from http:// responsibilitytoprotect.org/files/AU_Ezulwini\%20Consensus.pdf

Annan, K., 2000, We the peoples: The role of the United Nations in the 21st century, UN Department of Public Information, New York.

British Broadcasting Corporation (BBC), 2014, 'News Africa, "Burkina Faso Profile", viewed 02 December 2014, from http://www.bbc.com/news/world-africa-13072777

Dersso, S.A., Lulie, H., Assanvo, W., Louw-Vaudran, L. \& Atomssa, L., 2014, Peace \& Security Council Report, Addis Insight: Popular ousting of Compaoré not considered contrary to AU norms, Institute for Security Studies, Addis Ababa.

Evans, G. \& Sahnoun, M., 2002, 'The responsibility to protect', Council on Foreign Affairs 81(6), 99-110. https://doi.org/10.2307/20033347 
Human Rights Watch (HRW), 2012, 'DR Congo: Rwanda should stop aiding war crimes suspect', viewed 11 June 2012, from http://www.hrw.org/news/2012/06/03/drsuspect', viewed 11 June 2012,
congo-rwanda-should-stop-aidi

Human Rights Watch (HRW), 2013, 'DR Congo: M23 rebels kill, rape civilians: New evidence of Rwandan support for M23', viewed 14 August 2013, from https:// www.hrw.org/news/2013/07/22/dr-congo-m23-rebels-kill-rape-civilians

International Coalition for the Responsibility to Protect (ICRtoP), n.d., 'Africa', viewed 05 August 2013, from http://www.responsibilitytoprotect.org/index.php/africa? format=pdf

International Commission on Intervention and State Sovereignty (ICISS), 2001, 'The responsibility to protect: Report of the International Commission on Intervention and State Sovereignty', viewed 14 April 2011, from http://www.iciss.ca/report2 en.asp\#foreword

International Conference of the Great Lakes Region (ICGLR), 2006, Pact on security, stability and development in the Great Lakes region of the ICGLR, viewed 19 April 2010, from http://www.internal-displacement.org/8025708F004BE3B1/\%28http Lakes\%20pact_en.pdf

International Conference of the Great Lakes Region (ICGLR), 2012a, Declaration of the Heads of State and Government of the Members States of the ICGLR on the security situation in eastern DRC, Addis Ababa, viewed 09 September 2013 from http://www.disasterriskreduction.net/fileadmin/user_upload/drought/docs/ Declaration\%20English.pdf

International Conference of the Great Lakes Region (ICGLR), 2012b, Declaration of the Heads of State and Government of the Members States of the ICGLR on the security situation in eastern DRC, Kampala, viewed 07 September 2013, from https://icglr.org/IMG/pdf/Kampala_Declaration_August_2012-2.pdf

International Conference of the Great Lakes Region (ICGLR), 2012c, Declaration of the Heads of State and Government of the Member States of the ICGLR on the security situation in eastern DRC, Kampala.

International Conference of the Great Lakes Region (ICGLR), 2012d, Report of ICGLR regional inter-ministerial extraordinary meeting on the security situation in eastern DRC, Addis Ababa, viewed 09 September 2013, from http://www.genprev. net/wp-content/uploads/2012/08/Addis-RIMC-120711.pdf

International Conference of the Great Lakes Region (ICGLR), 2013a, Declaration of the Heads of State and Government of the Member States of the ICGLR on the security situation in eastern DRC, Nairobi.

International Conference of the Great Lakes Region (ICGLR), 2013b, Communication Officer on the Extraordinary Summit of Heads of State and Government of the ICGLR on Security Situation in eastern DRC, viewed 06 September 2013, from https://icglr.org/IMG/pdf/PressreleaseKampalaSummitSeptember2013.pdf

International Conference of the Great Lakes Region (ICGLR) and Southern African Development Community (SADC), 2013, Joint ICGLR-SADC Final Communiqué on Kampala Dialogue signed on 12 December 2013, viewed 13 December 2013, from http://www.sadc.int/files/8813/8718/4199/COMMUQUE_ENGLISH0001.pdf
International Criminal Court (ICC-01/04-01/06-2842), 2012, The Prosecutor v. Thomas Lubanga Dyilo., viewed 16 July 2014, from http://www.icc-cpi.int/iccdocs/doc/ doc1379838.pdf

Nanda, V.P., 2007, 'The protection of human rights under international law: Will the U.N. Human Rights Council and the Emerging New Norm "Responsibility To Protect' make a difference?"', Denver Journal of International Law and Policy 35(3/4), 353-378.

République Démocratique du Congo (RDC), 2009, Accord de Paix entre le Gouvernement de la RDC et le Congrès National pour la Défense du Peuple (CNDP) du 23 mars 2009.

Roberts, A. \& Zaum, D., 2008, Selective security: War and the United Nations Security Council since 1945, Routledge, London.

Stearns, J., 2012, From CNDP to M23: The evolution of an armed movement in eastern Congo, Rift Valley Institute, London.

UN Group of Experts of the DRC, 2013, Midterm report under resolution 1533, Inner City Press, viewed 09 September 2013, from http://www.innercitypress.com/ drcsanc0613repicp.html

United Nations General Assembly (UNGA) (A/RES/60/1), 2005, Resolution adopted by the General Assembly on 24 October 2005, viewed 04 September 2013, from http://daccess-dds-ny.un.org/doc/UNDOC/GEN/N05/487/60/PDF/N0548760. pdf?OpenElement

United Nations Joint Human Rights Office (UNJHRO), 2013, Report of the United Nations Joint Human Rights Office on Human Rights Violations perpetrated by soldiers of the Congolese Armed Forces and Combatants of the M23 in Goma and Sake, North Kivu Province, and in and around Minova, South Kivu Province, from Sake, North Kivu Province, and in and around Minova, South Kivu Province, from
15 November to 2 December 2012, viewed 13 May 2013, from http://reliefweb. int/sites/reliefweb.int/files/resources/UNJHRO $\% 20-\% 20 H R V$. $\% 20$ Goma $\% 20$ and $\% 20$ Minova $\% 20-\% 20$ May\%202013.pdf

United Nations Joint Human Rights Office (UNJHRO), 2014, Report of the United Nations Joint Human Rights Office on Human Rights Violations Committed by the Mouvement du 23 Mars (M23) in North Kivu Province April 2012-November 2013, viewed 20 October 2014, from http://www.ohchr.org/Documents/ Countries/CD/UNJHROOctober2014_en.pdf

United Nations Security Council (UNSC) (S/2012/348/Add.1), 2012a, Letter dated 26 June 2012 from the Chair of the Security Council Committee established pursuant to resolution 1533 (2004) concerning the Democratic Republic of the Congo addressed to the President of the Security Council, viewed 14 July 2012, from http://www.un.org/ga/search/view_doc.asp?symbol=S/2012/348/Add.1

United Nations Security Council (UNSC) (S/2012/843), 2012b, Letter dated 12 November 2012 from the Chair of the Security Council Committee established pursuant to resolution 1533 (2004) concerning the Democratic Republic of the Congo addressed to the President of the Security Council, viewed 22 April 2013, from http://www. un.org/ga/search/view_doc.asp?symbol=s/2012/843 